\title{
Localisation and Activation of the Neurokinin 1 Receptor in the Enteric Nervous System of the Mouse Distal Colon
}

\author{
Juan-Carlos Pelayo ${ }^{1}$, Nicholas A. Veldhuis ${ }^{2}$, Emily M. Eriksson ${ }^{3,4}$, Nigel W. Bunnett ${ }^{2,5 \dagger}$ and \\ Daniel P. Poole ${ }^{2,6 \dagger}$
}

1. Department of Pediatric Surgery, The University of Chicago, Chicago, IL 60637, USA

2. Monash Institute of Pharmaceutical Sciences, 381 Royal Parade, Parkville, VIC 3052, Australia

3. Division of Infection and Immunity, Walter and Eliza Hall Institute of Medical Research, Parkville, VIC 3052, Australia

4. Department of Medical Biology, The University of Melbourne, Parkville, VIC 3010, Australia

5. Department of Pharmacology, The University of Melbourne, Parkville, VIC 3010, Australia

6. Department of Anatomy and Neuroscience, The University of Melbourne, Parkville, VIC 3010, Australia

$\uparrow$ Corresponding authors. Daniel Poole and Nigel Bunnett

Daniel Poole, Ph.D., Monash Institute of Pharmaceutical Sciences, 381 Royal Parade, Parkville, VIC 3052, Australia. Tel: Office - +61 39903 9064; Email: Daniel.Poole@ Monash.edu

Nigel Bunnett, B.Sc., Ph.D., Monash Institute of Pharmaceutical Sciences, 381 Royal Parade, Parkville, VIC 3052, Australia. Tel: Office - +61 39903 9136; Mobile - +61 407392619. Facsimile: +61 39903 9581. Email: Nigel.Bunnett@Monash.edu

Funding: NIH/NIDDK grants DK07573 (JCP), DK39957, DK43207, and DK57840 (NWB), NHMRC grants 63303, 103188 (NWB) and 454858 (DPP) and Monash University (NWB)

Acknowledgments: Professors JB Furness and GW Aponte for providing antibodies used in this study 


\section{ABSTRACT}

Background \& Aims. The substance $\mathrm{P}$ neurokinin 1 receptor $\left(\mathrm{NK}_{1} \mathrm{R}\right)$ regulates motility, secretion, inflammation and pain in the intestine. The distribution of the $\mathrm{NK}_{1} \mathrm{R}$ is a key determinant of the functional effects of substance $\mathrm{P}$ in the gut. Information regarding the distribution of $\mathrm{NK}_{1} \mathrm{R}$ in subtypes of mouse enteric neurons is lacking, and is the focus of the present study.

Methods. $\mathrm{NK}_{1} \mathrm{R}$ immunoreactivity $\left(\mathrm{NK}_{1} \mathrm{R}-\mathrm{IR}\right)$ was examined in wholemount preparations of the mouse distal colon by indirect immunofluorescence and confocal microscopy. The distribution of $\mathrm{NK}_{1} \mathrm{R}$-IR expression within key functional neuronal subclasses was determined using established neurochemical markers.

Results. $\mathrm{NK}_{1} \mathrm{R}-\mathrm{IR}$ was expressed by a subpopulation of myenteric and submucosal neurons. $\mathrm{NK}_{1} \mathrm{R}$-IR was mainly detected in large, multipolar myenteric neurons and was colocalized with calcitonin gene-related peptide, neurofilament $\mathrm{M}$, choline acetyltransferase and calretinin. The remaining $\mathrm{NK}_{1} \mathrm{R}$-IR neurons were positive for nitric oxide synthase. The $\mathrm{NK}_{1} \mathrm{R}$ was expressed by the majority of submucosal neurons and was exclusively co-expressed with vasoactive intestinal peptide, with no overlap with choline acetyltransferase. Treatment with substance P resulted in the concentration-dependent internalisation of $\mathrm{NK}_{1} \mathrm{R}$ from the cell surface into endosome-like structures.

Discussion. Myenteric $\mathrm{NK}_{1} \mathrm{R}$ is mainly expressed by intrinsic primary afferent neurons, with minor expression by descending interneurons and inhibitory motor neurons. Submucosal $\mathrm{NK}_{1} \mathrm{R}$ is restricted to non-cholinergic secretomotor neurons. These findings highlight key differences in 
the neuronal distribution of $\mathrm{NK}_{1} \mathrm{R}-\mathrm{IR}$ between the mouse, rat and guinea pig, with important implications for the functional role of $\mathrm{NK}_{1} \mathrm{R}$ in regulating intestinal motility and secretion.

\section{Keywords: 5}

Enteric Nervous System, tachykinin, neurokinin 1 receptor, neurochemical coding, receptor trafficking

\section{INTRODUCTION}

The tachykinin family of neuropeptides control motility, secretion, inflammation and pain in the intestine (Steinhoff et al., in press). Tachykinins in the intestine, which mainly include substance $\mathrm{P}(\mathrm{SP})$ and neurokinin $\mathrm{A}$, derive from intrinsic neurons of the myenteric and submucosal plexuses, as well as from extrinsic neurons of the dorsal root ganglia. Tachykinins from enteric neurons promote peristalsis and secretion of electrolytes and fluid in the intestine (Holzer \& Holzer-Petsche, 1997a, b). Tachykinins that are released from the peripheral projections of primary spinal afferent neurons induce neurogenic inflammation of the intestine, and tachykinins that are released from the central projections of these neurons in the dorsal horn of the spinal cord promote visceral nociception (Steinhoff et al., in press). These actions of tachykinins are mediated by three neurokinin receptors $\left(\mathrm{NK}_{1} \mathrm{R}, \mathrm{NK}_{2} \mathrm{R}\right.$ and $\left.\mathrm{NK}_{3} \mathrm{R}\right)$. These receptors are all expressed within the gastrointestinal tract, with distributions best characterised for the guinea pig ileum (Portbury et al., 1996; Lomax et al., 1998). Both $\mathrm{NK}_{1} \mathrm{R}$ and $\mathrm{NK}_{3} \mathrm{R}$ are primarily expressed by neurons of the enteric nervous system (ENS), whereas $\mathrm{NK}_{2} \mathrm{R}$ is predominantly localized to gastrointestinal smooth muscle, nerve varicosities and the epithelium 
(Holzer \& Holzer-Petsche, 2001). Within the ENS, tachykinins acting via $\mathrm{NK}_{3} \mathrm{R}$ stimulate slow excitatory post-synaptic potentials (Bertrand \& Galligan, 1994) and enhance $\mathrm{Na}(\mathrm{v}) 1.9$ currents in intrinsic primary afferent neurons (IPANs) of the myenteric plexus (Copel et al., 2009). Recent evidence suggests a functional role for neuronal $\mathrm{NK}_{2} \mathrm{R}$, particularly in mediating contractile responses by the human intestine to electrical field stimulation (Lecci et al., 2006). The role of neuronal $\mathrm{NK}_{1} \mathrm{R}$ is less well-defined, but $\mathrm{SP}$ evokes $\mathrm{NK}_{1} \mathrm{R}$-dependent contractions of the intestine from a number of different species and plays a role in peristalsis (Nieuwmeyer et al., 2006). $\mathrm{NK}_{1} \mathrm{R}$ is also functionally expressed by intramuscular interstitial cells of Cajal (ICC) and may be involved in mediating the neurogenic effects of SP on gastrointestinal motility (Iino et al., 2004). The distribution and neurochemical coding of $\mathrm{NK}_{1} \mathrm{R}$ immunoreactive (-IR) enteric neurons has been characterized extensively in the small intestine of the guinea pig and rat (Portbury et al., 1996; Mann et al., 1999b), and to a lesser extent in that of the mouse and human (Smith et al., 1998; Vannucchi \& Faussone-Pellegrini, 2000). Comparatively fewer studies have examined $\mathrm{NK}_{1} \mathrm{R}$ expression in the colon (Bian et al., 2000; Harrington et al., 2005), despite its role in controlling spontaneous colonic motility (Lecci et al., 1997; Brierley et al., 2001) and water and electrolyte balance (Cooke et al., 1997), and in mediating the proinflammatory effects of SP (Steinhoff et al., in press). Moreover, there is limited information about the neuron-specific distribution of the $\mathrm{NK}_{1} \mathrm{R}$ in the intestine of the mouse (Vannucchi \& Faussone-Pellegrini, 2000), despite the wealth of information about the regulation of intestinal motility, secretion, inflammation and pain in this species. Knowledge of the expression of the $\mathrm{NK}_{1} \mathrm{R}$ by subtypes of enteric neurons can provide a mechanistic understanding of the actions of tachykinins within the intestine and can aid in predicting the functional consequences of $\mathrm{NK}_{1} \mathrm{R}$ activation or antagonism. In this study we have used a well-characterised antibody to $\mathrm{NK}_{1} \mathrm{R}$ combined with 
established neurochemical markers to characterise the distribution and activation of $\mathrm{NK}_{1} \mathrm{R}$ in the myenteric and submucosal plexuses of the mouse distal colon. We demonstrate $\mathrm{NK}_{1} \mathrm{R}$ expression by myenteric IPANs and submucosal non-cholinergic secretomotor neurons and identify significant interspecies differences in the distribution of $\mathrm{NK}_{1} \mathrm{R}$. These results provide, for the first time, an anatomical link with the existing literature on the role of the $\mathrm{NK}_{1} \mathrm{R}$ in regulating murine gastrointestinal function.

\section{MATERIALS AND METHODS}

Ethical Approval. All procedures on experimental animals were approved by The Institutional Animal Care and Use Committee of the University of California, San Francisco and the Monash University Animal Ethics Committee.

Animals. C57BL/6J mice (6-8 weeks, 20-25 g male and female) were from Charles River Laboratories (Hollister, CA) or from the Monash Animal Research Platform (Clayton, Victoria, Australia).

Tissue collection. Mice were killed by cervical dislocation and the distal colon was collected into cold phosphate buffered saline (PBS) containing nicardipine $(10 \mu \mathrm{M})$. Tissues were cleared of contents, opened along the mesenteric border and pinned tautly, mucosa-downwards onto sylgard-lined 35mm dishes. Preparations were then fixed in $4 \%$ paraformaldehyde (in PBS, $\mathrm{pH}$ 7.4) overnight at $4^{\circ} \mathrm{C}$. To facilitate detection of neuropeptides in the soma of neurons, mice were treated with colchicine $(2.5 \mathrm{mg} / \mathrm{kg}$, i.p.) 6 hours prior to tissue collection (Poole et al., 2011).

$\mathrm{NK}_{1} \mathrm{R}$ internalisation assays. Agonist-induced endocytosis of endogenous $\mathrm{NK}_{1} \mathrm{R}$ and Alexa594-conjugated SP (Alexa-SP) uptake was examined in organotypic preparations of the distal colon as described in detail (Pelayo et al., 2011). 
Reagents. The following compounds were obtained from the suppliers listed: nicardipine hydrochloride (Sigma-Aldrich, St Louis, MO, USA), SP (Bachem, Torrance, CA, USA), RP67580 (Tocris Bioscience, Ellisville, MO, USA), tetrodotoxin citrate (Alomone, Jerusalem, Israel). SP was labelled with Alexa594 dye and purified by HPLC as described (Bunnett et al., 1995).

Antibodies: A full list of primary antibodies used in this study is provided in Table 1. Secondary antibodies raised in donkeys were conjugated to Alexa Fluor 488, 594 or 647 (Invitrogen and Jackson Immunoresearch) and used at final dilutions of 1:500 or 1:1000.

Immunofluorescence. Myenteric and submucosal wholemounts and tissue sections of the distal colon (12 $\mu \mathrm{m}$ thickness cryosections) were prepared as described (Poole et al., 2011) and processed for immunofluorescence (Pelayo et al., 2011). Tissues were incubated with primary antisera for 48 hours at $4^{\circ} \mathrm{C}$ in blocking buffer (10\% normal horse serum, $0.1 \%$ Triton $\mathrm{X}-100$ in PBS containing 0.1\% sodium azide). Preparations were mounted in Prolong Gold (Invitrogen) and imaged using either Zeiss LSM510 META or Leica TCS SP8 confocal microscope systems.

Image analysis. Co-expression of $\mathrm{NK}_{1} \mathrm{R}$ with established neurochemical markers was determined manually from Z-stacked confocal images (Poole et al., 2011) and expressed as percentage overlap between the different neuronal populations. At least 3 mice were used for the analysis of each marker. The relative distribution of $\mathrm{NK}_{1} \mathrm{R}-\mathrm{IR}$ at the cell surface and within the cytosol was determined from captured images using ImageJ software (NIH) as described (Pelayo et al., 2011).

\section{RESULTS}


SP is detected in nerve fibres of extrinsic and intrinsic origin. The ENS is the major source of intestinal tachykinins, which derive from cholinergic excitatory motor neurons, ascending interneurons and intrinsic primary afferent neurons (IPANS) of the myenteric plexus and from submucosal IPANS (Furness, 2000). The colon also receives input from tachykinin-expressing primary spinal afferent neurons (Holzer \& Holzer-Petsche, 1997a), and SP is expressed by immune cells including macrophages and T lymphocytes (Koon \& Pothoulakis, 2006).

The distribution of SP-IR nerve fibres in the distal colon was examined in sections and in myenteric and submucosal wholemount preparations using a well-characterised antibody that detects tachykinins (Cuello et al., 1979). In tissue sections, SP-IR was detected in varicose nerve fibres running throughout the inner circular muscle of the muscularis externa and within the myenteric and submucosal ganglia (Fig. 1a, 1b). SP-IR nerve fibres innervating the mucosa were rarely observed (Ekblad et al., 1988; Sang \& Young, 1996). SP positive cells were also present throughout the lamina propria, suggesting expression by immune cells. In addition to its expression in varicose nerve fibres innervating submucosal ganglia, SP-IR was detected in nerve fibres running parallel to submucosal vessels (Fig. 1c). These fibres were also immunoreactive for calcitonin gene-related peptide (CGRP) and transient receptor potential vanilloid 1 (TRPV1) (Fig. 1d), an observation that is consistent with denervation and anatomical studies that have identified these as being of extrinsic origin (Costa et al., 1981; Ekblad et al., 1988; Galligan et $a l ., 1988)$. SP-IR fibres within submucosal ganglia were often detected independently of CGRPIR. In contrast, the majority of CGRP-positive fibres were also SP-IR. SP-IR is a marker of submucosal IPANs (Bornstein et al., 1989; Kirchgessner et al., 1992). SP-IR was not detected in submucosal neurons, consistent with evidence that there are no submucosal IPANs in the mouse ileum and colon (Figs. 1e, f) (Sang \& Young, 1996; Wong et al., 2008; Mongardi Fantaguzzi et 
al., 2009) and with studies demonstrating that SP-IR fibres innervating submucosal ganglia are of myenteric origin (Jessen et al., 1980; Costa et al., 1981).

In myenteric wholemount preparations, SP-positive fibres were dense throughout myenteric ganglia and also ran within and parallel to the circular muscle layer. There was no overlap between SP- and CGRP-positive varicosities in either region (Figs. 1g, h). As SP and CGRP are expressed by distinct functional subpopulations of myenteric neuron (Qu et al., 2008), this suggests that these fibres are of intrinsic origin. SP-positive fibres were also detected in wholemounts of submucosal ganglia, where they were less numerous than within myenteric ganglia.

These results confirm that the endogenous $\mathrm{NK}_{1} \mathrm{R}$ agonist $\mathrm{SP}$ is expressed in discrete regions of the colon wall and further extends these studies to define the distribution of SPpositive nerve fibres within enteric ganglia of the mouse colon.

$N K_{1} R$ is expressed by enteric neurons of the distal colon. In sections of the distal colon, $N K_{1} R-$ IR was detected in enteric ganglia (Fig. 1b) and in colonocytes (not shown). There was also weak $\mathrm{NK}_{1} \mathrm{R}-\mathrm{IR}$ in smooth muscle of the muscularis externa. Within enteric neurons $\mathrm{NK}_{1} \mathrm{R}-\mathrm{IR}$ was localised to the plasma membrane of the soma and neurites, with minimal intracellular stores. This was particularly evident for submucosal neurons where the majority of $\mathrm{NK}_{1} \mathrm{R}$-IR was cell surface associated. In submucosal wholemount preparations $\mathrm{NK}_{1} \mathrm{R}-\mathrm{IR}$ was expressed by the majority of all neurons in all ganglia examined. No $\mathrm{NK}_{1} \mathrm{R}$-IR was detected in fibres that were associated with the submucosal vasculature or lymphatics (Figs. 1c-f). $\mathrm{NK}_{1} \mathrm{R}-\mathrm{IR}$ was localised to a subset of large diameter, multi- and unipolar myenteric neurons (Fig. 1g). NK 1 R-IR was also present in ICCs within the myenteric and intramuscular levels, although this staining was weak 
relative to that of neurons and to other regions of the gut (not shown). There was no evidence for $\mathrm{NK}_{1} \mathrm{R}$ staining of enteric glial cells, as identified by double labelling against the glial marker glial fibrillary acidic protein (GFAP) (not shown).

$N K_{1} R-I R$ is expressed by non-cholinergic submucosal secretomotor neurons. Although there is good physiological evidence that activation of $\mathrm{NK}_{1} \mathrm{R}-\mathrm{IR}$ on submucosal neurons leads to their depolarization and to enhanced secretomotor activity (MacNaughton et al., 1997), the neuronal subtypes that express $\mathrm{NK}_{1} \mathrm{R}$ in these ganglia remain largely undefined. We examined the distribution and neurochemical coding of $\mathrm{NK}_{1} \mathrm{R}-\mathrm{IR}$ neurons in submucosal ganglia of the mouse distal colon. Prominent $\mathrm{NK}_{1} \mathrm{R}$-IR was detected in the majority of PGP9.5-IR submucosal neurons (86\%, 248/ 288 neurons), where it was localised to the plasma membrane of the soma and neurites (Fig. 2a-2a"). Where neurites were clearly visible, these neurons were generally unipolar and had smooth cell bodies. Neurons with very weak intensity staining or no detectable staining were considered to be negative for $\mathrm{NK}_{1} \mathrm{R}$-IR for the purposes of this study. The $\mathrm{NK}_{1} \mathrm{R}-\mathrm{IR}$ expressing population was further characterized using established neurochemical markers for different neuronal subtypes present in the murine submucosal plexus (Mongardi Fantaguzzi et al., 2009). All NK $\mathrm{NK}_{1}$-IR neurons were calretinin-IR (100\%, 143/143 neurons), whereas $84 \%$ of calretinin positive neurons (143/170 neurons) were also $\mathrm{NK}_{1} \mathrm{R}$-IR (Fig. 2b-b”). All NK $\mathrm{N}_{1} \mathrm{R}-\mathrm{IR}$ neurons were VIP-IR (99\%, 170/171 neurons) (Fig. 2c-c"). Most NK ${ }_{1}$ R-IR neurons were NPYIR (Fig. 2d-d"), indicating that, as in the ileum, extensive overlap between the VIP-IR and NPYIR subpopulations of neurons also occurs in the distal colon of the mouse. The extensive colocalisation between neurofilament $\mathrm{M}$ (NFM) and $\mathrm{NK}_{1} \mathrm{R}-\mathrm{IR}$ (not quantified) (Fig. 3d-d") suggests that NFM is mainly expressed by non-cholinergic secretomotor neurons. In contrast, 
there was minimal overlap between $\mathrm{NK}_{1} \mathrm{R}-\mathrm{IR}$ and either ChAT-IR (1\%, 2/275 neurons; Fig. 2ee") or somatostatin (0\%, 1/225 neurons; Fig. 2f-f'), which are specifically localised to cholinergic secretomotor neurons (De Jonge et al., 2003; Mongardi Fantaguzzi et al., 2009). These neurons were relatively lower in abundance than those positive for VIP or NPY. Similarly, there was almost no overlap between $\mathrm{NK}_{1} \mathrm{R}$ and CGRP, with only $2 \%$ of the $\mathrm{NK}_{1} \mathrm{R}$ population also immunopositive for CGRP (1/54 neurons; Fig. 3a-a"). CGRP is an established marker of $\mathrm{AH}$ neurons in other species, and is expressed by submucosal cholinergic secretomotor neurons of the mouse (Mongardi Fantaguzzi et al., 2009). SP, another potential IPAN marker was not detected within the somata of submucosal neurons, although there was an extensive network of SP-IR varicosities closely associated with $\mathrm{NK}_{1} \mathrm{R}$-IR neurons (Fig. 1e, f). NK $\mathrm{N}_{1}$-IR and NOS-IR were often present in the same neurons, and 29\% (56/196 neurons) of all $\mathrm{NK}_{1} \mathrm{R}$-IR neurons were also NOS-IR (Fig. 3b-b"). In contrast to the ileum (Mongardi Fantaguzzi et al., 2009), no tyrosine hydroxylase positive neurons were detected in submucosal ganglia using the same antibody (0/64 neurons, 3 mice), and immunoreactivity was restricted to nerve fibres associated with ganglia and submucosal vasculature (Wong et al., 2008) (Fig 3c-c"). All counts are summarized in Table 2. In summary, $\mathrm{NK}_{1} \mathrm{R}$-IR is expressed by most submucosal neurons of the mouse distal colon. $\mathrm{NK}_{1} \mathrm{R}-\mathrm{IR}$ neurons have the neurochemical composition of non-cholinergic secretomotor neurons.

$N K_{1} R-I R$ is expressed by myenteric intrinsic primary afferent neurons. Tachykinins released from SP-positive circular muscle motor neurons regulate migrating motor complexes in the colon (Foxx-Orenstein \& Grider, 1996; Brierley et al., 2001; Mule et al., 2007) and mediate a noncholinergic component of the peristaltic reflex (Holzer \& Holzer-Petsche, 1997a; Lecci et al., 
1997). Although these studies predict that $\mathrm{NK}_{1} \mathrm{R}$ is expressed by cholinergic and nitrergic neurons of the colon (Mule et al., 2007), the in-depth analysis of $\mathrm{NK}_{1} \mathrm{R}$ expression by myenteric neurons in this region is lacking.

$\mathrm{NK}_{1} \mathrm{R}$-IR was present in a subset of PGP9.5-IR myenteric neurons of the distal colon (22\%, 152/684, Fig. 4a-a"). These neurons were large, multipolar and had prominent neurites. $\mathrm{NK}_{1} \mathrm{R}$-IR was detected at the plasma membrane of the soma and neurites, with comparatively little cytosolic staining. Double labelling using markers of IPANs (Furness et al., 2004b) indicated that $76 \%$ (59/78 neurons) of $\mathrm{NK}_{1} \mathrm{R}$-IR neurons were also CGRP-IR (Fig. 4b-b") and that many of these were also immunoreactive for neurofilament $\mathrm{M}$ (not quantified), which enables observation of neuronal morphology (Fig. 4c-c") (Qu et al., 2008). Nearly all NK $\mathrm{N}_{1} \mathrm{R}-\mathrm{IR}$ neurons coexpressed calretinin-IR (95\%, 124/130 neurons, Fig. 4d-d"), a putative marker of IPANs and other neurons in the mouse (Furness et al., 2004a; Qu et al., 2008) and rat (Mann et al., 1997). Moreover, there was also extensive colocalization with ChAT-IR (88\%, 118/ 134 neurons; Fig. 5a-a”). The remaining $\mathrm{NK}_{1} \mathrm{R}-\mathrm{IR}$ neurons were NOS-IR (9\%, 21/ 230 neurons; Fig. 5b-b"). No overlap between $\mathrm{NK}_{1} \mathrm{R}-\mathrm{IR}$ and SP was observed (0\%, 0/ 71 neurons; Fig. 5c-c"). Internalisation of Alexa-SP was used to identify $\mathrm{NK}_{1} \mathrm{R}$-expressing neurons (Jenkinson et al., 1999), allowing examination of overlap between $\mathrm{NK}_{1} \mathrm{R}$ and markers for which only rabbit antibodies were available. There was little colocalization between $\mathrm{NK}_{1} \mathrm{R}$ (detected by internalization of Alexa-SP, $100 \mathrm{nM}, 30 \mathrm{~min}$ treatment) and the somatostatin 2A receptor (SSTR2A), a mediator of the descending inhibitory component of the peristaltic reflex (Grider, 2003) (not shown). The majority of SSTR2A-IR neurons were Alexa-SP negative (88 \%, 21/24 neurons), consistent with the localization of SSTR2A to NOS-IR neurons (Zhao et al., 2013). Similarly, most Alexa-SP-positive neurons were negative for SSTR2A-IR. In summary, our data 
indicate that $\mathrm{NK}_{1} \mathrm{R}-\mathrm{IR}$ in the myenteric plexus of the mouse distal colon is largely restricted to IPANs.

$N K_{I} R$ is functionally expressed by submucosal neurons. To assess the activation of the $N K_{1} R$ in submucosal neurons, we examined agonist-stimulated endocytosis of the $\mathrm{NK}_{1} \mathrm{R}$. Previous studies have utilized endocytosis as an indicator of receptor activation in endothelial cells and neurons (Bowden et al., 1994; Marvizon et al., 1997). Treatment with Alexa-SP (100 nM, 30 min) resulted in the presence of Alexa-SP positive endosome-like structures throughout the soma and neurites of both submucosal and myenteric neurons (Fig. 6a, a'). These possible endosomes were also $\mathrm{NK}_{1} \mathrm{R}$-IR, indicating that internalization of both receptor and agonist had occurred (Fig. 6b-b"). Alexa-SP labelling was restricted to the cell surface of the soma and neurites following Alexa-SP binding at $4^{\circ} \mathrm{C}$ without warming, a temperature at which endocytosis is significantly inhibited (Grady et al., 1996). Both endocytosis of $\mathrm{NK}_{1} \mathrm{R}-\mathrm{IR}$ and uptake of AlexaSP were not observed following prior treatment with the $\mathrm{NK}_{1} \mathrm{R}$ antagonist RP-67580 (10 $\mu \mathrm{M}$, not shown), a concentration that effectively abolishes $\mathrm{NK}_{1} \mathrm{R}$-dependent signalling in enteric neurons (Pelayo et al., 2011). Neurons with Alexa-SP labelled endosome-like structures were $\mathrm{NK}_{1} \mathrm{R}-\mathrm{IR}$ and were also immunoreactive for NPY or ChAT (SMP and MP, respectively, not shown). Internalisation of submucosal $\mathrm{NK}_{1} \mathrm{R}-\mathrm{IR}$ in response to unlabelled $\mathrm{SP}$ was concentration dependent (100 pM - $1 \mu \mathrm{M})$. Significant receptor endocytosis relative to untreated controls was detected at concentrations of $1 \mathrm{nM}$ and greater (Fig. 6c-c"'”, d). Thus, we conclude that $\mathrm{NK}_{1} \mathrm{R}$ is functionally expressed by submucosal neurons of the mouse distal colon and that the antibody that we have used specifically detects $\mathrm{NK}_{1} \mathrm{R}-\mathrm{IR}$ in mouse tissues. 


\section{Discussion}

The functional subtypes of enteric neurons can be readily identified by their neurochemical content, morphology and projections. These neurons have been comprehensively categorized in the guinea pig ileum (Costa et al., 1996). However, despite the wealth of information about patho-physiological processes in the intestine of the mouse, the neurochemical characterization of murine enteric neurons is incomplete (Sang \& Young, 1996; Sang et al., 1997; Qu et al., 2008; Mongardi Fantaguzzi et al., 2009). To provide a mechanistic understanding of the functions of the $\mathrm{NK}_{1} \mathrm{R}$ in this species, we have completed a comprehensive study of the localization of the $\mathrm{NK}_{1} \mathrm{R}$ in enteric neurons of the mouse colon.

$\mathrm{NK}_{1} R$ is expressed by myenteric IPANs, descending interneurons and inhibitory motor neurons. Our results show that the $\mathrm{NK}_{1} \mathrm{R}$ is expressed by myenteric IPANs, descending interneurons and inhibitory motor neurons of the mouse distal colon. Expression of $\mathrm{NK}_{1} \mathrm{R}$ by myenteric IPANs is supported by the following observations. $\mathrm{NK}_{1} \mathrm{R}-\mathrm{IR}$ neurons were morphologically defined as Dogiel Type II due to their large, round cell bodies and the presence of multiple axons. Moreover, $\mathrm{NK}_{1} \mathrm{R}-\mathrm{IR}$ was generally coexpressed with the established IPAN marker CGRP (Grider, 1994; Furness et al., 2004b). There was also extensive colocalization between $\mathrm{NK}_{1} \mathrm{R}-\mathrm{IR}$ and the neurochemical markers NFM and calretinin, which are expressed by IPANs and other neurons in the mouse myenteric plexus (Furness et al., 2004b; Qu et al., 2008). IPANs are cholinergic (Furness et al., 2004a) and accordingly the majority of $\mathrm{NK}_{1} \mathrm{R}-\mathrm{IR}$ neurons were also ChAT positive. The remaining neurons were most likely to be inhibitory motor neurons and descending interneurons. This conclusion is based on the overlap with NOS-IR and SSTR2A-IR, and the presence of $\mathrm{NK}_{1} \mathrm{R}-\mathrm{IR}$ neurons that were ChAT negative. The colocalization between NK1R-IR and somatostatin-IR is consistent with expression of $\mathrm{NK}_{1} \mathrm{R}-\mathrm{IR}$ by at least one 
class of descending interneuron (Costa et al., 1996; Grider, 2003). These are medium-sized neurons that are also ChAT-IR (De Jonge et al., 2003; Qu et al., 2008). The lack of apparent overlap between $\mathrm{NK}_{1} \mathrm{R}-\mathrm{IR}$ and SP-IR would preclude expression by ascending interneurons, as these are tachykininergic in both mouse and guinea small intestine (Qu et al., 2008).

$N K_{I} R$ is expressed by submucosal non-cholinergic secretomotor/vasodilator neurons. There are relatively few studies of the neurochemical composition of murine submucosal neurons (Sang \& Young, 1996; Mongardi Fantaguzzi et al., 2009; Poole et al., 2011). Our results indicate that $\mathrm{NK}_{1} \mathrm{R}$-IR is exclusively expressed by non-cholinergic secretomotor neurons. Support for this conclusion is based on two lines of evidence. Firstly, all $\mathrm{NK}_{1} \mathrm{R}$-IR neurons of the submucosal plexus of the mouse colon also expressed VIP, a marker of non-cholinergic secretomotor submucosal neurons that is conserved across multiple species, including humans (Porter et al., 1999). Thus, the $\mathrm{NK}_{1} \mathrm{R}-\mathrm{IR}$ is exclusively expressed by non-cholinergic secretomotor submucosal neurons. Moreover, nearly all VIP-IR neurons were also $\mathrm{NK}_{1} \mathrm{R}$ positive. Secondly, there was no overlap between $\mathrm{NK}_{1} \mathrm{R}-\mathrm{IR}$ and ChAT, somatostatin or CGRP, all of which are markers of cholinergic neurons in mouse submucosal ganglia (Sang \& Young, 1996; De Jonge et al., 2003; Mongardi Fantaguzzi et al., 2009). In the mouse ileum, the VIP-positive population can be further subdivided into secretomotor and vasodilator neurons based on their expression of TH (Mongardi Fantaguzzi et al., 2009). It was not possible to undertake an equivalent characterisation of $\mathrm{NK}_{1} \mathrm{R}$-IR neurons in the distal colon as we were unable to detect $\mathrm{TH}$-positive submucosal neurons in this region using the identical antibody. TH-IR in these preparations was restricted to nerve fibres associated with the submucosal vasculature and ganglia (Wong et al., 2008). This is in accordance with the significantly lower population of TH-positive neurons in submucosal ganglia of the distal colon relative to other regions (Chalazonitis et al., 2011). 
The distribution of $N K_{1} R$ differs markedly between species. The findings of this study highlight clear differences between $\mathrm{NK}_{1} \mathrm{R}$-IR distributions in the guinea pig, rat and mouse. In submucosal ganglia of the guinea pig ileum, the $\mathrm{NK}_{1} \mathrm{R}-\mathrm{IR}$ is primarily localised to secretomotor neurons containing NPY-IR and ChAT-IR (Portbury et al., 1996; Moore et al., 1997; Lomax et al., 1998). In the guinea pig colon, the majority of $\mathrm{NK}_{1} \mathrm{R}-\mathrm{IR}$ submucosal neurons are cholinergic, with expression in other neuron types including IPANs (Harrington et al., 2005). These findings are consistent with the distribution predicted by functional studies of tachykinin-mediated chloride secretion and neuron depolarization (Frieling et al., 1999). In the rat distal colon, the $\mathrm{NK}_{1} \mathrm{R}$ colocalizes with SP in Dogiel type II submucosal neurons (Mitsui, 2010). The present results clearly demonstrate that the $\mathrm{NK}_{1} \mathrm{R}$ is expressed by non-cholinergic secretomotor neurons in the submucosal plexus of the mouse distal colon. Previous studies (Wong et al., 2008; Mongardi Fantaguzzi et al., 2009; Poole et al., 2011) and the present results show that, in marked contrast to the guinea pig and rat, there is extensive overlap between NPY and VIP positive neuronal populations and little evidence for submucosal IPANs in the mouse colon. This relative structural simplicity of the mouse submucosal plexus may underlie the differences in $\mathrm{NK}_{1} \mathrm{R}$ distribution that we observe. Whether these differences translate to species-specific differences in SP-mediated neurogenic control of fluid and electrolyte secretion in the intestine remain to be determined.

In the myenteric plexus of the guinea pig ileum, the $\mathrm{NK}_{1} \mathrm{R}$ is mainly expressed by NOSIR inhibitory motor neurons, with excitatory motor neurons, secretomotor neurons and a minor proportion of IPANs making up the remaining $\mathrm{NK}_{1} \mathrm{R}$-positive neuronal population (Lomax et al., 1998). In the guinea pig distal colon, there are comparatively fewer $\mathrm{NK}_{1} \mathrm{R}-\mathrm{IR}$ myenteric neurons, and these co-express NOS, ChAT or calbindin (Bian et al., 2000; Harrington et al., 2005).The 
distribution of the $\mathrm{NK}_{1} \mathrm{R}$ in the rat ileum differs from the guinea pig, with the $\mathrm{NK}_{1} \mathrm{R}$ localized to myenteric IPANs (Mann et al., 1997) and often coexpressed with SP (Mann et al., 1999a; Mitsui, 2011). Based on these studies our data suggest that the distribution of $\mathrm{NK}_{1} \mathrm{R}$ in the myenteric plexus of the mouse colon is most similar to that in the rat.

Few studies have examined the distribution of $\mathrm{NK}_{1} \mathrm{R}$ in the human ENS, probably due to a lack of suitable means of detection. Immunohistochemical and in situ hybridisation studies show that the $\mathrm{NK}_{1} \mathrm{R}$ is expressed by enteric neurons of the human antrum, duodenum and colon (Smith et al., 1998; Goode et al., 2000; Smith et al., 2000; Boutaghou-Cherid et al., 2006). Functional studies demonstrate that the $\mathrm{NK}_{1} \mathrm{R}$ mediates non-adrenergic non-cholinergic neuromuscular transmission to the circular muscle of the human ileum (Zagorodnyuk et al., 1997) and regulates neurogenic contractions of the isolated colon (Cellek et al., 2006; Guagnini et al., 2006).

Functional implications of $\mathrm{NK}_{1} R$ distribution in inflammatory bowel disease. Myenteric $\mathrm{NK}_{1} \mathrm{R}$ is unlikely to play a role in enhanced nociceptive signalling from the colon, such as occurs in irritable bowel syndrome (IBS) or inflammatory bowel disease (IBD). The neurons identified as $\mathrm{NK}_{1} \mathrm{R}$-positive in the present study do not project centrally and are therefore not involved in the transduction of noxious stimuli to the spinal cord. Although $\mathrm{NK}_{1} \mathrm{R}$ is expressed by dorsal root ganglion neurons (Zhang et al., 2007), whether colonic primary spinal afferents are $\mathrm{NK}_{1} \mathrm{R}$ positive is presently unknown.

There is an increased capsaicin-evoked SP release from extrinsic nerve fibres innervating the colon in experimental colitis. Mice deficient in SP have reduced inflammation following dextran sulphate sodium treatment relative to wild type mice (Engel et al., 2012). Furthermore, extrinsic denervation or pharmacological inhibition of $\mathrm{NK}_{1} \mathrm{R}$ also significantly attenuates 
experimental colitis (Castagliuolo et al., 2002; Landau et al., 2007; Gad et al., 2009). $\mathrm{NK}_{1} \mathrm{R}$ expression is upregulated in the colon of patients with IBD (Goode et al., 2000) and in animal models of colitis (Kimball et al., 2007). The internalization of $\mathrm{NK}_{1} \mathrm{R}$ is indicative of localised release of SP at sites of inflammation (Bowden et al., 1994). The increased release of SP in IBD is supported by our own preliminary data which shows that myenteric $\mathrm{NK}_{1} \mathrm{R}$ is largely internalized in a model of chronic colitis (Cattaruzza et al., 2013). This would effectively prevent $\mathrm{NK}_{1} \mathrm{R}$ from signalling at the cell surface and is consistent with a loss of neuronal $\mathrm{NK}_{1} \mathrm{R}$ function in IBD (Smith \& Smid, 2005) and experimental colitis (Hosseini et al., 1999), and to a reduction in gastrointestinal tachykininergic signalling in general (Al-Saffar \& Hellstrom, 2001). We report that myenteric $\mathrm{NK}_{1} \mathrm{R}-\mathrm{IR}$ is mostly expressed by neurochemically-defined IPANs. These neurons determine the magnitude and type of reflexes that are initiated by different stimuli, and intestinal inflammation leads to their hyperexcitability (Furness et al., 2004a). The functional consequences of inflammation on $\mathrm{NK}_{1} \mathrm{R}$-dependent signalling by these neurons are presently unknown. As IPANs are key integrators of reflex activity, effective block of $\mathrm{NK}_{1} \mathrm{R}$ signalling through internalization could potentially affect all physiological reflexes mediated by the myenteric plexus, including coordinated motility patterns.

The $\mathrm{NK}_{1} \mathrm{R}$ is involved in secretory reflex pathways in the intestine and has a potential role in toxin-induced hypersecretion. $\mathrm{NK}_{1} \mathrm{R}$ has a pro-secretory role in the intestine, determined pharmacologically using $\mathrm{NK}_{1} \mathrm{R}$-selective antagonists (Frieling et al., 1999; Riegler et al., 1999). In the present study we have identified VIP-positive non-cholinergic secretomotor/ vasodilator neurons as the major $\mathrm{NK}_{1} \mathrm{R}-\mathrm{IR}$ population. Activation of $\mathrm{NK}_{1} \mathrm{R}$ expressed by these neurons would be expected to promote secretion. $\mathrm{NK}_{1} \mathrm{R}$ antagonists attenuate cholera-associated hypersecretion (Turvill et al., 2000) and suppress cholera toxin-induced hyperexcitability of 
submucosal neurons (Gwynne et al., 2009). Internalization of $\mathrm{NK}_{1} \mathrm{R}$ in enteric neurons occurs following exposure to Toxin A, the causative agent of Clostridium difficile-induced ileitis. Toxin A stimulates release of SP from afferent fibres and inhibition of $\mathrm{NK}_{1} \mathrm{R}$ or genetic deletion of $\mathrm{NK}_{1} \mathrm{R}$ prevents Toxin A induced tissue damage (Mantyh et al., 1996).

In summary, we have described the neurochemical coding of $\mathrm{NK}_{1} \mathrm{R}$-IR neurons in the mouse distal colon. We have discussed the neuronal subtypes by which this receptor is expressed and the differences in $\mathrm{NK}_{1} \mathrm{R}$ distribution across commonly used laboratory species. The findings of this work will directly relate to physiological studies of the role of $\mathrm{NK}_{1} \mathrm{R}$ in the gut and the effects that drugs targeting $\mathrm{NK}_{1} \mathrm{R}$ activity have on colonic motility and secretion. 


\section{Figure Descriptions}

Figure 1. Distribution of $N K_{1} R$ and its endogenous agonist substance $P$ in the mouse distal colon. a, b: SP-IR was detected in enteric ganglia and in nerve fibres within the inner circular muscle layer (arrowheads). SP-positive cells were also detected throughout the mucosa (arrows). $\mathrm{NK}_{1} \mathrm{R}$-IR was mainly localised to submucosal $(\mathbf{c}, \mathbf{e}, \mathbf{f})$ and myenteric neurons $(\mathbf{b}, \mathbf{g}, \mathbf{h})$. $\mathbf{c}, \mathbf{d}$ : SPIR was detected in nerve fibres associated with submucosal arterioles (asterisk) and to submucosal ganglia (box). d: SP-IR innervating arterioles (asterisk) were also CGRP- and TRPV1-IR (arrowheads). e, f: SP-IR (arrowheads with asterisks) was often closely associated with $\mathrm{NK}_{1} \mathrm{R}$ positive submucosal neurons, and expression was largely distinct to CGRP-IR varicosities (arrows). Coexpression of SP-IR and CGRP-IR are indicated with arrowheads. g: $\mathrm{NK}_{1} \mathrm{R}$-IR myenteric neurons were generally large and often multipolar. SP-IR (arrowheads with asterisks) and CGRP-IR (arrows) were in distinct fibres and varicosities. Scale: a, b: $50 \mu \mathrm{m}, \mathbf{c - h}$ : $20 \mu \mathrm{m} . \operatorname{lm}$ : longitudinal muscle layer, $\mathrm{cm}$ : circular muscle layer, $m p$ : myenteric plexus.

Figure 2. NK $R$-IR is localized to non-cholinergic secretomotor/vasodilator neurons of the submucosal plexus. a-a": $\mathrm{NK}_{1} \mathrm{R}-\mathrm{IR}$ was expressed by the majority of PGP9.5-IR neurons of the distal colon (arrowheads). All $\mathrm{NK}_{1} \mathrm{R}-\mathrm{IR}$ neurons were also calretinin-IR (b-b") and were identified as non-cholinergic secretomotor neurons based on extensive colocalization with VIPIR (c-c") and NPY-IR (d-d") (arrowheads) and the lack of overlap between $\mathrm{NK}_{1} \mathrm{R}-\mathrm{IR}$ and ChAT (e-e") or somatostatin-IR (f-f") populations (arrowheads with asterisks). Scale: $20 \mu \mathrm{m}$.

Figure 3. Neurochemical coding of $N K_{1} R-I R$ submucosal neurons. a-a": $N_{1} R$ and CGRP immunoreactivities were detected in distinct populations of neurons (arrowheads with asterisks). In contrast, the majority of NOS (b-b") and NFM (d-d") positive neurons expressed $\mathrm{NK}_{1} \mathrm{R}-\mathrm{IR}$ 
(arrowheads). TH-IR was restricted to nerve fibres, with no evidence for TH-positive submucosal neurons (c-c"s). Scale: $20 \mu \mathrm{m}$.

Figure 4. $N K_{1} R-I R$ is primarily localized to myenteric intrinsic primary afferent neurons of the colon. a-a": $\mathrm{NK}_{1} \mathrm{R}-\mathrm{IR}$ was expressed by relatively large diameter PGP9.5-IR neurons which were often multipolar (arrowheads). There was extensive overlap between $\mathrm{NK}_{1} \mathrm{R}$-IR and the putative IPAN markers CGRP (b-b"), NFM (c-c") and calretinin (d-d") (arrowheads). Scale: 20 $\mu \mathrm{m}$

Figure 5. NK $R$-IR is coexpressed with NOS and ChAT in the myenteric plexus. The majority of $\mathrm{NK}_{1} \mathrm{R}$-IR neurons were ChAT-IR (a-a") (arrowheads). Conversely, a minority of $\mathrm{NK}_{1} \mathrm{R}-\mathrm{IR}$ neurons were also NOS-IR (b-b") (arrowheads). There was no detectable overlap between $\mathrm{NK}_{1} \mathrm{R}$ and SP-expressing neuronal populations (c-c"s) (arrowheads with asterisks). Scale: $20 \mu \mathrm{m}$.

Figure 6. SP-evoked $N K_{1} R$ endocytosis and recycling in submucosal neurons. a-a': Treatment with Alexa594-conjugated SP (Alexa-SP, $100 \mathrm{nM}, 30 \mathrm{~min}$ ) resulted in endosomal labelling of a subset of submucosal and myenteric neurons (arrowheads). b-b": Endosomal Alexa-SP labelling was coincident with $\mathrm{NK}_{1} \mathrm{R}-\mathrm{IR}$ (arrows). c-c" ${ }^{9}$, $\mathrm{d}$ : In untreated neurons $\mathrm{NK}_{1} \mathrm{R}-\mathrm{IR}$ was mainly localized to the plasma membrane of the soma and neurites (arrowheads). Treatment with SP (0.1-1000 $\mathrm{nM}, 30 \mathrm{~min})$ resulted in the concentration-dependent trafficking of $\mathrm{NK}_{1} \mathrm{R}-\mathrm{IR}$ to endosome-like structures (arrows). $* * * p \leq 0.001$. Scale: $20 \mu \mathrm{m}$. 


\section{REFERENCES}

Al-Saffar A \& Hellstrom PM. (2001). Contractile responses to natural tachykinins and selective tachykinin analogs in normal and inflamed ileal and colonic muscle. Scand $J$ Gastroenterol 36, 485-493.

Bertrand PP \& Galligan JJ. (1994). Contribution of chloride conductance increase to slow EPSC and tachykinin current in guinea-pig myenteric neurones. The Journal of physiology 481 ( Pt 1), 47-60.

Bian XC, Bertrand PP, Furness JB \& Bornstein JC. (2000). Evidence for functional NK1tachykinin receptors on motor neurones supplying the circular muscle of guinea-pig small and large intestine. Neurogastroenterology and motility : the official journal of the European Gastrointestinal Motility Society 12, 307-315.

Bornstein JC, Furness JB \& Costa M. (1989). An electrophysiological comparison of substance P-immunoreactive neurons with other neurons in the guinea-pig submucous plexus. Journal of the autonomic nervous system 26, 113-120.

Boutaghou-Cherid H, Porcher C, Liberge M, Jule Y, Bunnett NW \& Christen MO. (2006). Expression of the neurokinin type 1 receptor in the human colon. Autonomic neuroscience : basic \& clinical 124, 9-17.

Bowden JJ, Garland AM, Baluk P, Lefevre P, Grady EF, Vigna SR, Bunnett NW \& McDonald DM. (1994). Direct observation of substance P-induced internalization of neurokinin 1 (NK1) receptors at sites of inflammation. Proceedings of the National Academy of Sciences of the United States of America 91, 8964-8968.

Brierley SM, Nichols K, Grasby DJ \& Waterman SA. (2001). Neural mechanisms underlying migrating motor complex formation in mouse isolated colon. British journal of pharmacology 132, 507-517.

Bunnett NW, Dazin PF, Payan DG \& Grady EF. (1995). Characterization of receptors using cyanine 3-labeled neuropeptides. Peptides 16, 733-740.

Castagliuolo I, Morteau O, Keates AC, Valenick L, Wang CC, Zacks J, Lu B, Gerard NP \& Pothoulakis C. (2002). Protective effects of neurokinin-1 receptor during colitis in mice: role of the epidermal growth factor receptor. British journal of pharmacology 136, 271279. 
Cattaruzza F, Poole DP \& Bunnett NW. (2013). Arresting inflammation: contributions of plasma membrane and endosomal signalling to neuropeptide-driven inflammatory disease. Biochem Soc Trans 41, 137-143.

Cellek S, John AK, Thangiah R, Dass NB, Bassil AK, Jarvie EM, Lalude O, Vivekanandan S \& Sanger GJ. (2006). 5-HT4 receptor agonists enhance both cholinergic and nitrergic activities in human isolated colon circular muscle. Neurogastroenterology and motility: the official journal of the European Gastrointestinal Motility Society 18, 853-861.

Chalazonitis A, Tang AA, Shang Y, Pham TD, Hsieh I, Setlik W, Gershon MD \& Huang EJ. (2011). Homeodomain interacting protein kinase 2 regulates postnatal development of enteric dopaminergic neurons and glia via BMP signaling. The Journal of neuroscience : the official journal of the Society for Neuroscience 31, 13746-13757.

Cooke HJ, Sidhu M, Fox P, Wang YZ \& Zimmermann EM. (1997). Substance P as a mediator of colonic secretory reflexes. The American journal of physiology 272, G238-245.

Copel C, Osorio N, Crest M, Gola M, Delmas P \& Clerc N. (2009). Activation of neurokinin 3 receptor increases $\mathrm{Na}(\mathrm{v}) 1.9$ current in enteric neurons. The Journal of physiology 587, 1461-1479.

Costa M, Brookes SJ, Steele PA, Gibbins I, Burcher E \& Kandiah CJ. (1996). Neurochemical classification of myenteric neurons in the guinea-pig ileum. Neuroscience 75, 949-967.

Costa M, Furness JB, Llewellyn-Smith IJ \& Cuello AC. (1981). Projections of substance Pcontaining neurons within the guinea-pig small intestine. Neuroscience 6, 411-424.

Cuello AC, Galfre G \& Milstein C. (1979). Detection of substance P in the central nervous system by a monoclonal antibody. Proceedings of the National Academy of Sciences of the United States of America 76, 3532-3536.

De Jonge F, Van Nassauw L, De Man JG, De Winter BY, Van Meir F, Depoortere I, Peeters TL, Pelckmans PA, Van Marck E \& Timmermans JP. (2003). Effects of Schistosoma mansoni infection on somatostatin and somatostatin receptor $2 \mathrm{~A}$ expression in mouse ileum. Neurogastroenterology and motility : the official journal of the European Gastrointestinal Motility Society 15, 149-159.

Ekblad E, Ekman R, Hakanson R \& Sundler F. (1988). Projections of peptide-containing neurons in rat colon. Neuroscience 27, 655-674. 
Engel MA, Khalil M, Mueller-Tribbensee SM, Becker C, Neuhuber WL, Neurath MF \& Reeh PW. (2012). The proximodistal aggravation of colitis depends on substance P released from TRPV1-expressing sensory neurons. Journal of gastroenterology 47, 256-265.

Foxx-Orenstein AE \& Grider JR. (1996). Regulation of colonic propulsion by enteric excitatory and inhibitory neurotransmitters. The American journal of physiology 271, G433-437.

Frieling T, Dobreva G, Weber E, Becker K, Rupprecht C, Neunlist M \& Schemann M. (1999). Different tachykinin receptors mediate chloride secretion in the distal colon through activation of submucosal neurones. Naunyn-Schmiedeberg's archives of pharmacology 359, 71-79.

Furness JB. (2000). Types of neurons in the enteric nervous system. Journal of the autonomic nervous system 81, 87-96.

Furness JB, Jones C, Nurgali K \& Clerc N. (2004a). Intrinsic primary afferent neurons and nerve circuits within the intestine. Progress in neurobiology 72, 143-164.

Furness JB, Robbins HL, Xiao J, Stebbing MJ \& Nurgali K. (2004b). Projections and chemistry of Dogiel type II neurons in the mouse colon. Cell and tissue research 317, 1-12.

Gad M, Pedersen AE, Kristensen NN, Fernandez Cde F \& Claesson MH. (2009). Blockage of the neurokinin 1 receptor and capsaicin-induced ablation of the enteric afferent nerves protect SCID mice against T-cell-induced chronic colitis. Inflammatory bowel diseases 15, 1174-1182.

Galligan JJ, Costa M \& Furness JB. (1988). Changes in surviving nerve fibers associated with submucosal arteries following extrinsic denervation of the small intestine. Cell and tissue research 253, 647-656.

Goode T, O'Connell J, Anton P, Wong H, Reeve J, O'Sullivan GC, Collins JK \& Shanahan F. (2000). Neurokinin-1 receptor expression in inflammatory bowel disease: molecular quantitation and localisation. Gut 47, 387-396.

Grady EF, Gamp PD, Jones E, Baluk P, McDonald DM, Payan DG \& Bunnett NW. (1996). Endocytosis and recycling of neurokinin 1 receptors in enteric neurons. Neuroscience 75, 1239-1254. 
Grider JR. (1994). CGRP as a transmitter in the sensory pathway mediating peristaltic reflex. The American journal of physiology 266, G1139-1145.

Grider JR. (2003). Neurotransmitters mediating the intestinal peristaltic reflex in the mouse. The Journal of pharmacology and experimental therapeutics 307, 460-467.

Guagnini F, Valenti M, Mukenge S, Matias I, Bianchetti A, Di Palo S, Ferla G, Di Marzo V \& Croci T. (2006). Neural contractions in colonic strips from patients with diverticular disease: role of endocannabinoids and substance P. Gut 55, 946-953.

Gwynne RM, Ellis M, Sjovall H \& Bornstein JC. (2009). Cholera toxin induces sustained hyperexcitability in submucosal secretomotor neurons in guinea pig jejunum. Gastroenterology 136, 299-308 e294.

Harrington AM, Hutson JM \& Southwell BR. (2005). Immunohistochemical localization of substance P NK1 receptor in guinea pig distal colon. Neurogastroenterology and motility : the official journal of the European Gastrointestinal Motility Society 17, 727-737.

Holzer P \& Holzer-Petsche U. (1997a). Tachykinins in the gut. Part I. Expression, release and motor function. Pharmacology \& therapeutics 73, 173-217.

Holzer P \& Holzer-Petsche U. (1997b). Tachykinins in the gut. Part II. Roles in neural excitation, secretion and inflammation. Pharmacology \& therapeutics 73, 219-263.

Holzer P \& Holzer-Petsche U. (2001). Tachykinin receptors in the gut: physiological and pathological implications. Current opinion in pharmacology 1, 583-590.

Hosseini JM, Goldhill JM, Bossone C, Pineiro-Carrero V \& Shea-Donohue T. (1999). Progressive alterations in circular smooth muscle contractility in TNBS-induced colitis in rats. Neurogastroenterology and motility : the official journal of the European Gastrointestinal Motility Society 11, 347-356.

Iino S, Ward SM \& Sanders KM. (2004). Interstitial cells of Cajal are functionally innervated by excitatory motor neurones in the murine intestine. The Journal of physiology 556, 521530.

Jenkinson KM, Morgan JM, Furness JB \& Southwell BR. (1999). Neurons bearing NK(3) tachykinin receptors in the guinea-pig ileum revealed by specific binding of fluorescently labelled agonists. Histochemistry and cell biology 112, 233-246. 
Jessen KR, Polak JM, Van Noorden S, Bloom SR \& Burnstock G. (1980). Peptide-containing neurones connect the two ganglionated plexuses of the enteric nervous system. Nature 283, 391-393.

Kimball ES, Prouty SP, Pavlick KP, Wallace NH, Schneider CR \& Hornby PJ. (2007). Stimulation of neuronal receptors, neuropeptides and cytokines during experimental oil of mustard colitis. Neurogastroenterology and motility : the official journal of the European Gastrointestinal Motility Society 19, 390-400.

Kirchgessner AL, Tamir H \& Gershon MD. (1992). Identification and stimulation by serotonin of intrinsic sensory neurons of the submucosal plexus of the guinea pig gut: activityinduced expression of Fos immunoreactivity. The Journal of neuroscience : the official journal of the Society for Neuroscience 12, 235-248.

Koon HW \& Pothoulakis C. (2006). Immunomodulatory properties of substance P: the gastrointestinal system as a model. Annals of the New York Academy of Sciences 1088, 23-40.

Landau AM, Yashpal K, Cahill CM, St Louis M, Ribeiro-da-Silva A \& Henry JL. (2007). Sensory neuron and substance $\mathrm{P}$ involvement in symptoms of a zymosan-induced rat model of acute bowel inflammation. Neuroscience 145, 699-707.

Lecci A, Capriati A, Altamura M \& Maggi CA. (2006). Tachykinins and tachykinin receptors in the gut, with special reference to NK2 receptors in human. Autonomic neuroscience : basic \& clinical 126-127, 232-249.

Lecci A, Tramontana M, Giuliani S \& Maggi CA. (1997). Role of tachykinin NK1 and NK2 receptors on colonic motility in anesthetized rats: effect of agonists. Canadian journal of physiology and pharmacology $\mathbf{7 5}, 582-586$.

Lomax AE, Bertrand PP \& Furness JB. (1998). Identification of the populations of enteric neurons that have NK1 tachykinin receptors in the guinea-pig small intestine. Cell and tissue research 294, 27-33.

MacNaughton W, Moore B \& Vanner S. (1997). Cellular pathways mediating tachykinin-evoked secretomotor responses in guinea pig ileum. The American journal of physiology 273, G1127-1134. 
Mann PT, Furness JB \& Southwell BR. (1999a). Choline acetyltransferase immunoreactivity of putative intrinsic primary afferent neurons in the rat ileum. Cell and tissue research 297, 241-248.

Mann PT, Southwell BR, Ding YQ, Shigemoto R, Mizuno N \& Furness JB. (1997). Localisation of neurokinin 3 (NK3) receptor immunoreactivity in the rat gastrointestinal tract. Cell and tissue research $\mathbf{2 8 9}, 1-9$.

Mann PT, Southwell BR \& Furness JB. (1999b). Internalization of the neurokinin 1 receptor in rat myenteric neurons. Neuroscience 91, 353-362.

Mantyh CR, Pappas TN, Lapp JA, Washington MK, Neville LM, Ghilardi JR, Rogers SD, Mantyh PW \& Vigna SR. (1996). Substance P activation of enteric neurons in response to intraluminal Clostridium difficile toxin A in the rat ileum. Gastroenterology 111, $1272-1280$.

Marvizon JC, Martinez V, Grady EF, Bunnett NW \& Mayer EA. (1997). Neurokinin 1 receptor internalization in spinal cord slices induced by dorsal root stimulation is mediated by NMDA receptors. The Journal of neuroscience : the official journal of the Society for Neuroscience 17, 8129-8136.

Mitsui R. (2010). Immunohistochemical characteristics of submucosal Dogiel type II neurons in rat colon. Cell and tissue research 340, 257-265.

Mitsui R. (2011). Immunohistochemical analysis of substance P-containing neurons in rat small intestine. Cell and tissue research 343, 331-341.

Mongardi Fantaguzzi C, Thacker M, Chiocchetti R \& Furness JB. (2009). Identification of neuron types in the submucosal ganglia of the mouse ileum. Cell and tissue research 336, $179-189$.

Moore BA, Vanner S, Bunnett NW \& Sharkey KA. (1997). Characterization of neurokinin-1 receptors in the submucosal plexus of guinea pig ileum. The American journal of physiology 273, G670-678.

Mule F, Amato A \& Serio R. (2007). Role for NK(1) and NK(2) receptors in the motor activity in mouse colon. European journal of pharmacology 570, 196-202. 
Nieuwmeyer F, Ye J \& Huizinga JD. (2006). Ava[L-Pro9,N-MeLeu10] substance P(7-11) (GR 73632) and Sar9, Met(O2)11 increase distention-induced peristalsis through activation of neurokinin-1 receptors on smooth muscle and interstitial cells of cajal. The Journal of pharmacology and experimental therapeutics 317, 439-445.

Pelayo JC, Poole DP, Steinhoff M, Cottrell GS \& Bunnett NW. (2011). Endothelin-converting enzyme-1 regulates trafficking and signalling of the neurokinin 1 receptor in endosomes of myenteric neurones. The Journal of physiology 589, 5213-5230.

Poole DP, Pelayo JC, Scherrer G, Evans CJ, Kieffer BL \& Bunnett NW. (2011). Localization and regulation of fluorescently labeled delta opioid receptor, expressed in enteric neurons of mice. Gastroenterology 141, 982-991 e981-988.

Portbury AL, Furness JB, Young HM, Southwell BR \& Vigna SR. (1996). Localisation of NK1 receptor immunoreactivity to neurons and interstitial cells of the guinea-pig gastrointestinal tract. The Journal of comparative neurology 367, 342-351.

Porter AJ, Wattchow DA, Brookes SJ \& Costa M. (1999). Projections of nitric oxide synthase and vasoactive intestinal polypeptide-reactive submucosal neurons in the human colon. Journal of gastroenterology and hepatology 14, 1180-1187.

Qu ZD, Thacker M, Castelucci P, Bagyanszki M, Epstein ML \& Furness JB. (2008). Immunohistochemical analysis of neuron types in the mouse small intestine. Cell and tissue research 334, 147-161.

Riegler M, Castagliuolo I, So PT, Lotz M, Wang C, Wlk M, Sogukoglu T, Cosentini E, Bischof G, Hamilton G, Teleky B, Wenzl E, Matthews JB \& Pothoulakis C. (1999). Effects of substance $\mathrm{P}$ on human colonic mucosa in vitro. The American journal of physiology 276, G1473-1483.

Sang Q, Williamson S \& Young HM. (1997). Projections of chemically identified myenteric neurons of the small and large intestine of the mouse. Journal of anatomy 190 ( Pt 2), 209-222.

Sang Q \& Young HM. (1996). Chemical coding of neurons in the myenteric plexus and external muscle of the small and large intestine of the mouse. Cell and tissue research 284, 39-53.

Smith AS \& Smid SD. (2005). Impaired capsaicin and neurokinin-evoked colonic motility in inflammatory bowel disease. Journal of gastroenterology and hepatology 20, 697-704. 
Smith VC, Sagot MA, Couraud JY \& Buchan AM. (1998). Localization of the neurokinin 1 (NK-1) receptor in the human antrum and duodenum. Neuroscience letters $\mathbf{2 5 3}, 49-52$.

Smith VC, Sagot MA, Wong H \& Buchan AM. (2000). Cellular expression of the neurokinin 1 receptor in the human antrum. Journal of the autonomic nervous system 79, 165-172.

Steinhoff M, von Mentzer B, Geppetti P, Pothoulakis C \& Bunnett NW. (in press). Tachykinins and their receptors: contributions to the physiological control and the mechanisms of disease. Physiological Reviews.

Turvill JL, Connor P \& Farthing MJ. (2000). Neurokinin 1 and 2 receptors mediate cholera toxin secretion in rat jejunum. Gastroenterology 119, 1037-1044.

Vannucchi MG \& Faussone-Pellegrini MS. (2000). NK1, NK2 and NK3 tachykinin receptor localization and tachykinin distribution in the ileum of the mouse. Anatomy and embryology 202, 247-255.

Wong V, Blennerhassett M \& Vanner S. (2008). Electrophysiological and morphological properties of submucosal neurons in the mouse distal colon. Neurogastroenterology and motility : the official journal of the European Gastrointestinal Motility Society 20, 725734.

Zagorodnyuk V, Santicioli P, Turini D \& Maggi CA. (1997). Tachykinin NK1 and NK2 receptors mediate non-adrenergic non-cholinergic excitatory neuromuscular transmission in the human ileum. Neuropeptides 31, 265-271.

Zhang H, Cang CL, Kawasaki Y, Liang LL, Zhang YQ, Ji RR \& Zhao ZQ. (2007). Neurokinin-1 receptor enhances TRPV1 activity in primary sensory neurons via PKCepsilon: a novel pathway for heat hyperalgesia. The Journal of neuroscience : the official journal of the Society for Neuroscience 27, 12067-12077.

Zhao P, Canals M, Murphy JE, Klingler D, Eriksson EM, Pelayo JC, Hardt M, Bunnett NW \& Poole DP. (2013). Agonist-biased Trafficking of Somatostatin Receptor 2A in Enteric Neurons. The Journal of biological chemistry 288, 25689-25700. 

Table 1. Sources and dilutions of primary antibodies.

\begin{tabular}{|l|l|l|l|}
\hline Antigen & Species & Dilution & Source \\
\hline Calretinin & Goat & $1: 500$ & SWANT, Bellinzona, Switzerland \\
\hline ChAT & Goat & $1: 200$ & Millipore, Temecula, CA \\
\hline CGRP & Goat & $1: 1,000$ & Abcam Inc., Cambridge, MA \\
\hline GFAP & Goat & $1: 400$ & Novus Biologicals, Littleton, CO \\
\hline NFM & Chicken & $1: 500$ & Gene Tex Inc., Irvine, CA \\
\hline Neurokinin 1 Receptor & Rabbit & $1: 1,000$ & CURE, UCLA, \#94168 \\
\hline NOS & Goat & $1: 500$ & Novus \\
\hline NPY & Rabbit & $1: 400$ & CURE, UCLA \#8711 \\
\hline NPY & Sheep & $1: 200$ & Millipore, AB1583 \\
\hline PGP9.5 & Chicken & $1: 500$ & Abcam \\
\hline Somatostatin & Sheep & $1: 800$ & Gift from Dr G.W. Aponte, UC Berkeley \\
\hline Somatostatin 2A receptor & Rabbit & $1: 2,000$ & CURE, UCLA \#9431 \\
\hline Substance P & Guinea Pig & $1: 200$ & Neuromics, Edina, MN \\
\hline Substance P & Rat & $1: 800$ & Novus, clone NC1/34 \\
\hline TRPV1 & Rabbit & $1: 2000$ & Neuromics \\
\hline Tyrosine Hydroxylase & Sheep & $1: 500$ & Millipore, AB1542 \\
\hline VIP & Sheep & $1: 200$ & Abcam \\
\hline
\end{tabular}


Table 2. Summary of $\mathrm{NK}_{1} \mathrm{R}$ distribution in neurochemically-defined subclasses of submucosal neurons.

\begin{tabular}{|l|l|l|l|l|l|l|l|l|}
\hline & PGP9.5 & VIP & NPY & CGRP & ChAT & Calretinin & SOM & NOS \\
\hline $\mathrm{NK}_{1} \mathrm{R} /+$ & $\begin{array}{l}100 \% \\
(248 / 248)\end{array}$ & $\begin{array}{l}99 \% \\
(170 / 171)\end{array}$ & $\begin{array}{l}88 \% \\
(175 / 200)\end{array}$ & $\begin{array}{l}2 \% \\
(1 / 54)\end{array}$ & $\begin{array}{l}1 \% \\
(2 / 275)\end{array}$ & $\begin{array}{l}100 \% \\
(143 / 143)\end{array}$ & $\begin{array}{l}0 \% \\
(1 / 225)\end{array}$ & $\begin{array}{l}29 \% \\
(56 / 196)\end{array}$ \\
\hline $\mathrm{NK}_{1} \mathrm{R} /-$ & $0 \%$ & $1 \%$ & $12 \%$ & $98 \%$ & $99 \%$ & $0 \%$ & $100 \%$ & $71 \%$ \\
& $(0 / 248)$ & $(1 / 171)$ & $(25 / 200)$ & $(53 / 54)$ & $(273 / 275)$ & $(0 / 143)$ & $\begin{array}{l}(224 / 22 \\
5)\end{array}$ & $(140 / 196)$ \\
\hline$+\mathrm{NK}_{1} \mathrm{R}$ & $\begin{array}{l}86 \% \\
(248 / 288)\end{array}$ & $\begin{array}{l}94 \% \\
(170 / 181)\end{array}$ & $\begin{array}{l}97 \% \\
(175 / 181)\end{array}$ & $\begin{array}{l}5 \% \\
(1 / 20)\end{array}$ & $\begin{array}{l}4 \% \\
(2 / 50)\end{array}$ & $\begin{array}{l}84 \% \\
(143 / 170)\end{array}$ & $\begin{array}{l}3 \% \\
(1 / 36)\end{array}$ & $\begin{array}{l}73 \% \\
(56 / 77)\end{array}$ \\
\hline$+/-$ & $14 \%$ & $6 \%$ & $3 \%$ & $95 \%$ & $96 \%$ & $16 \%$ & $97 \%$ & $27 \%$ \\
& $(40 / 288)$ & $(11 / 181)$ & $(6 / 181)$ & $(19 / 20)$ & $(48 / 50)$ & $(27 / 170)$ & $(35 / 36)$ & $(21 / 77)$ \\
\hline
\end{tabular}

$\mathrm{NK}_{1} \mathrm{R} /+$ : $\mathrm{NK}_{1} \mathrm{R}$ positive, neurochemical marker positive

$N_{1} R /$-: $N_{1} R$ positive, negative for neurochemical marker

+/NK $\mathrm{NK}_{1} \mathrm{R}$ : Neurochemical marker positive, $\mathrm{NK}_{1} \mathrm{R}$ positive

+/-: Neurochemical marker positive, $\mathrm{NK}_{1} \mathrm{R}$ negative

${ }^{\text {a }}$ All $\mathrm{NK}_{1} \mathrm{R}$ positive neurons are also PGP9.5 positive (248/ 248 neurons)

b $86 \%$ of all PGP9.5 positive neurons are also $\mathrm{NK}_{1} \mathrm{R}$ positive (248/ 288 neurons) 
Table 3. Summary of $\mathrm{NK}_{1} \mathrm{R}$ distribution in neurochemically-defined subclasses of myenteric neurons.

\begin{tabular}{|l|l|l|l|l|l|l|l|l|}
\hline & PGP9.5 & NOS & ChAT & Calretinin & SP & CGRP & SOM & SSTR2A \\
\hline $\mathrm{NK}_{1} \mathrm{R} /+$ & $\begin{array}{l}100 \% \\
(152 / 152)\end{array}$ & $\begin{array}{l}9 \% \\
(21 / 230)\end{array}$ & $\begin{array}{l}88 \% \\
(118 / 134)\end{array}$ & $\begin{array}{l}95 \% \\
(124 / 130)\end{array}$ & $\begin{array}{l}0 \% \\
(0 / 71)\end{array}$ & $\begin{array}{l}76 \% \\
(59 / 78)\end{array}$ & $\begin{array}{l}17 \% \\
(7 / 42)\end{array}$ & $\begin{array}{l}13 \% \\
(3 / 24)\end{array}$ \\
\hline $\mathrm{NK}_{1} \mathrm{R} /-$ & $0 \%$ & $91 \%$ & $12 \%$ & $5 \%$ & $100 \%$ & $24 \%$ & $83 \%$ & $87 \%$ \\
& $(0 / 152)$ & $(209 / 230)$ & $(16 / 134)$ & $(6 / 130)$ & $(71 / 71)$ & $(19 / 78)$ & $(35 / 42)$ & $(21 / 24)$ \\
\hline$+/ \mathrm{NK}_{1} \mathrm{R}$ & $22 \%$ & $4 \%$ & $33 \%$ & $59 \%$ & $0 \%$ & $83 \%$ & $7 \%$ & $11 \%$ \\
& $(152 / 684)$ & $(21 / 591)$ & $(118 / 357)$ & $(124 / 211)$ & $(0 / 65)$ & $(59 / 71)$ & $(7 / 29)$ & $(3 / 28)$ \\
\hline$+/-$ & $78 \%$ & $96 \%$ & $67 \%$ & $41 \%$ & $100 \%$ & $17 \%$ & $76 \%$ & $89 \%$ \\
& $(532 / 684)$ & $(570 / 591)$ & $(239 / 357)$ & $(87 / 211)$ & $(65 / 65)$ & $(12 / 71)$ & $(22 / 29)$ & $(25 / 28)$ \\
\hline
\end{tabular}

$\mathrm{NK}_{1} \mathrm{R} /+$ : $\mathrm{NK}_{1} \mathrm{R}$ positive, neurochemical marker positive

$\mathrm{NK}_{1} \mathrm{R} /$-: $\mathrm{NK}_{1} \mathrm{R}$ positive, negative for neurochemical marker

$+/ \mathrm{NK}_{1} \mathrm{R}$ : Neurochemical marker positive, $\mathrm{NK}_{1} \mathrm{R}$ positive

+/-: Neurochemical marker positive, $\mathrm{NK}_{1} \mathrm{R}$ negative

${ }^{\mathrm{a}}$ All $\mathrm{NK}_{1} \mathrm{R}$ positive neurons are also PGP9.5 positive (152/ 152 neurons)

b $22 \%$ of all PGP9.5 positive neurons are also $\mathrm{NK}_{1} \mathrm{R}$ positive (152/ 684 neurons) 

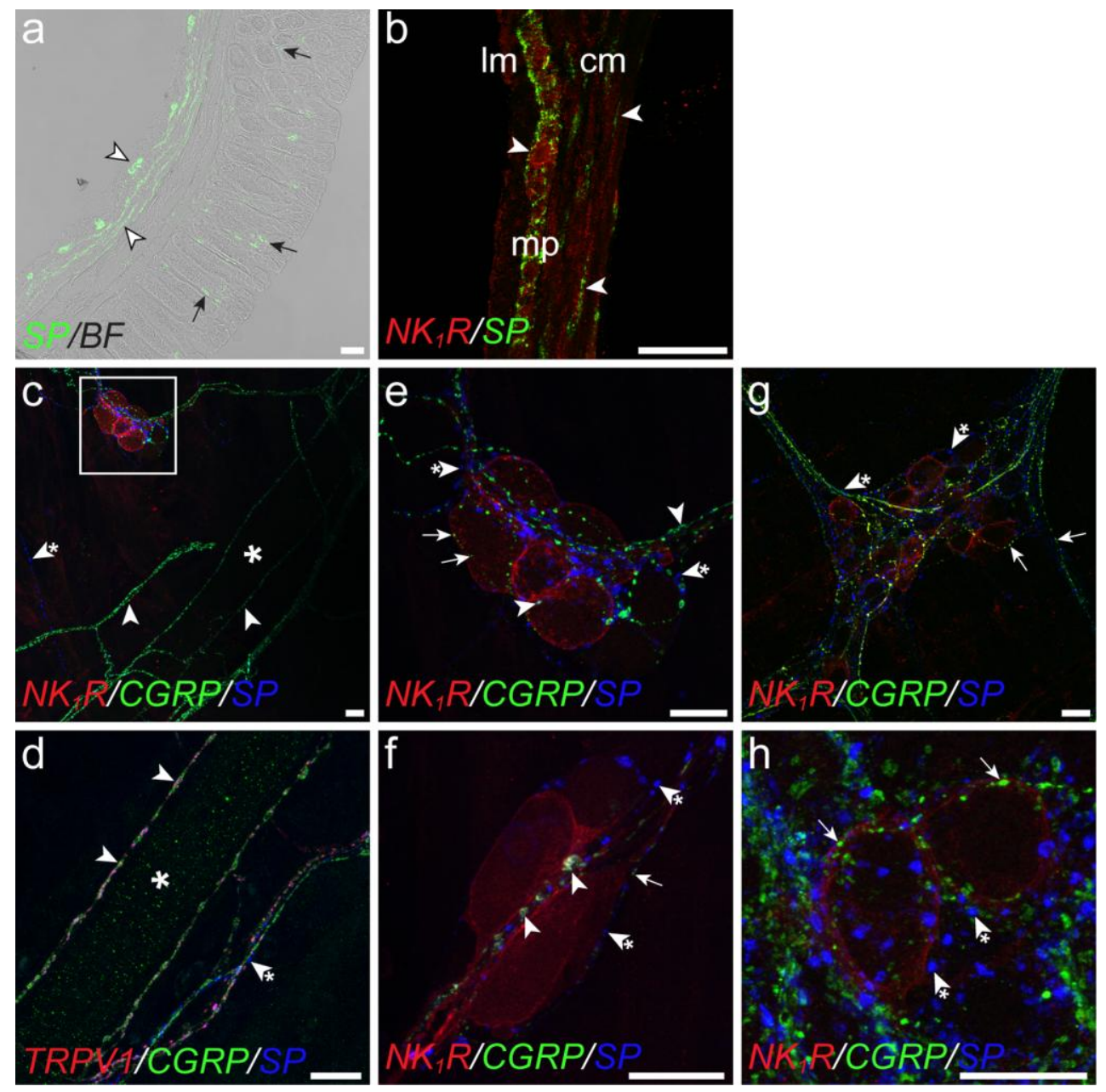


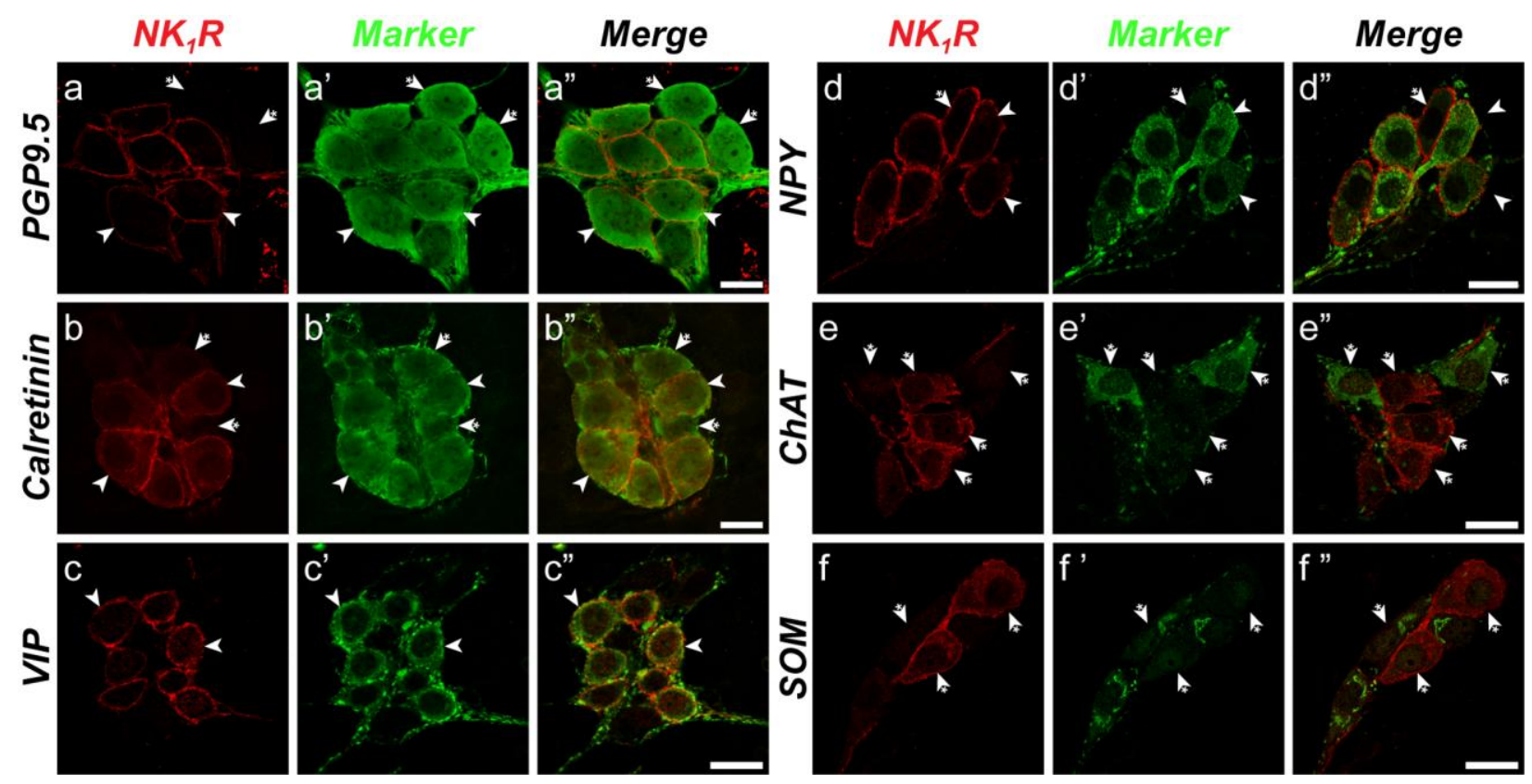




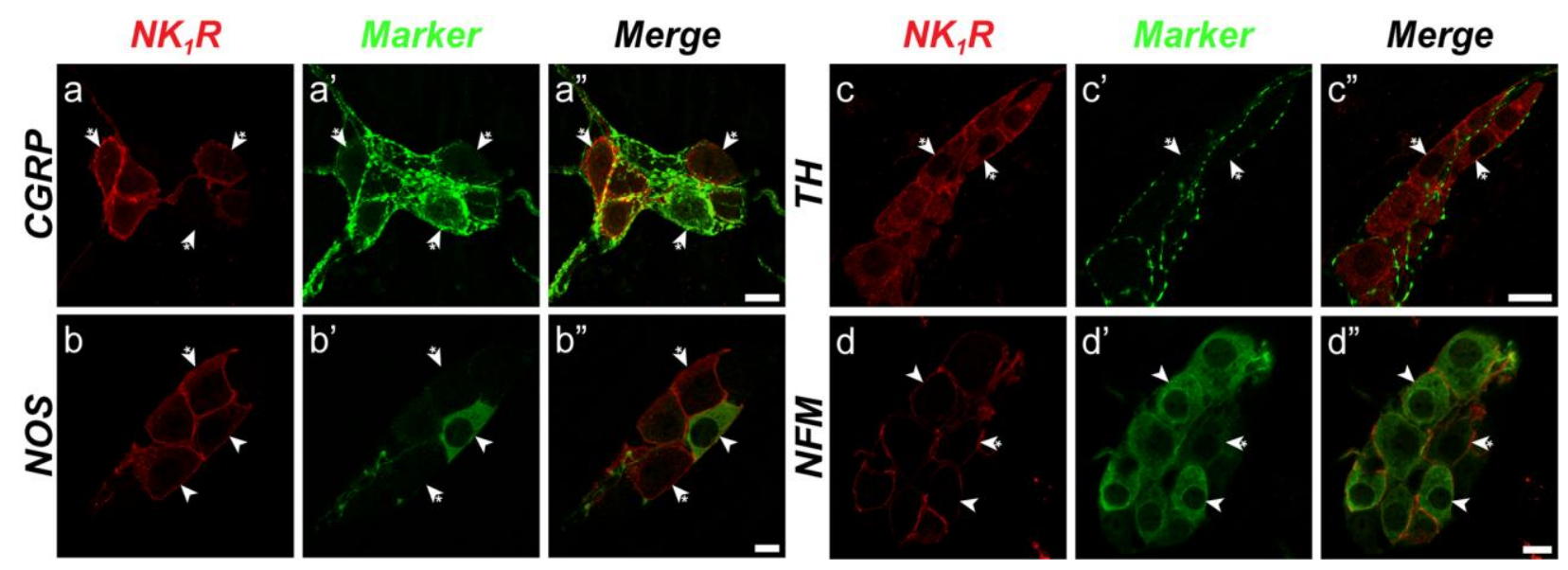




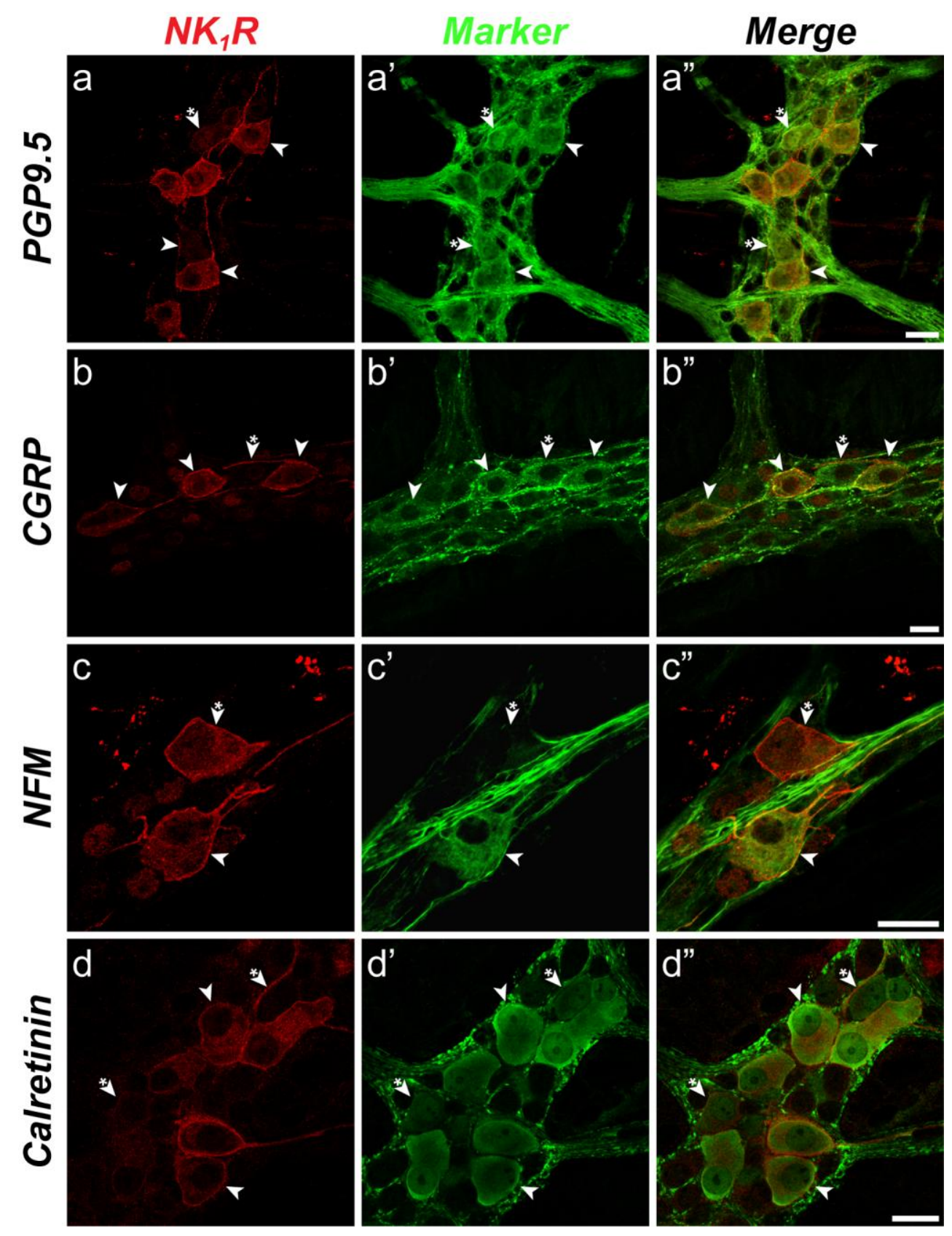



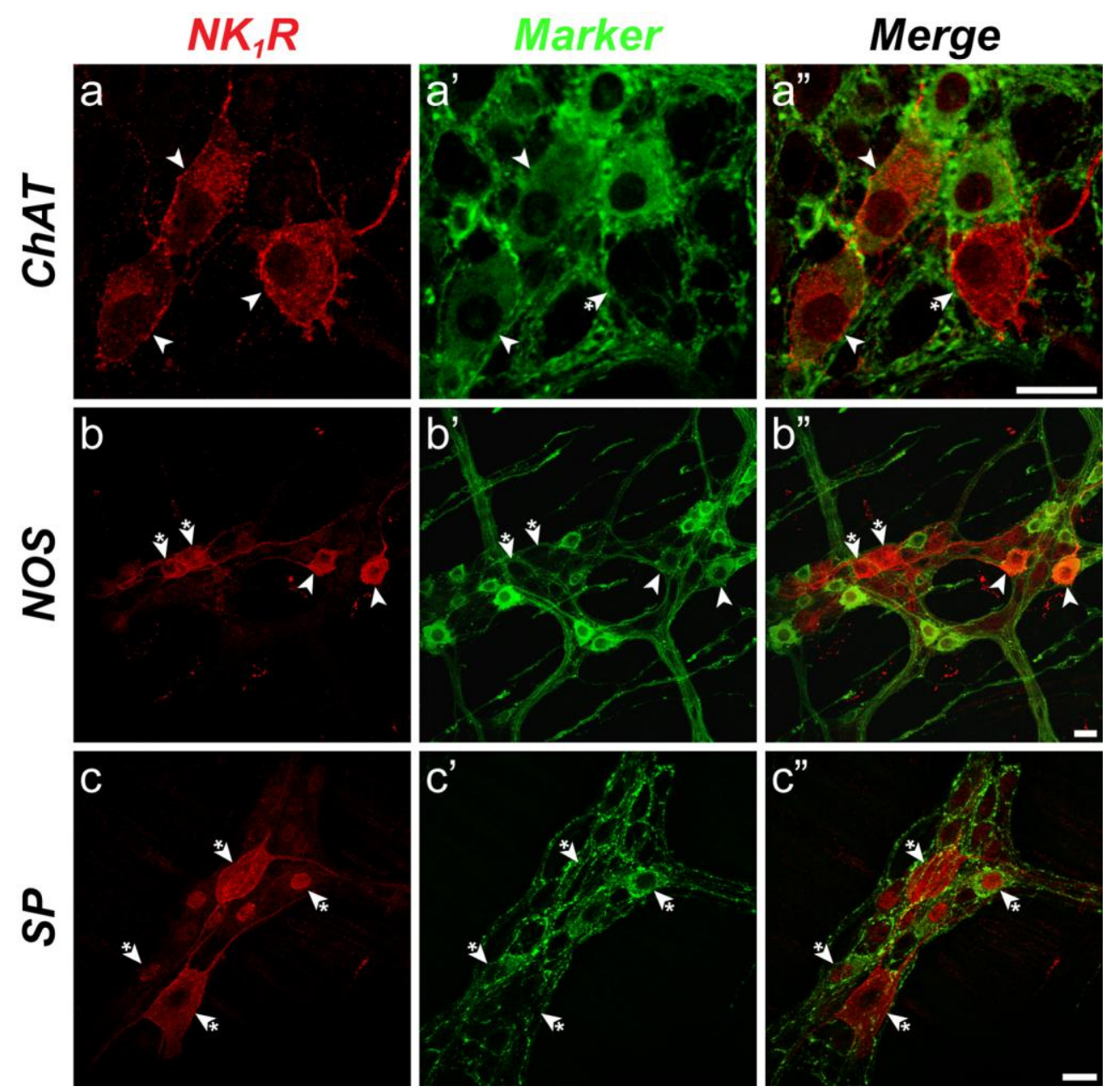


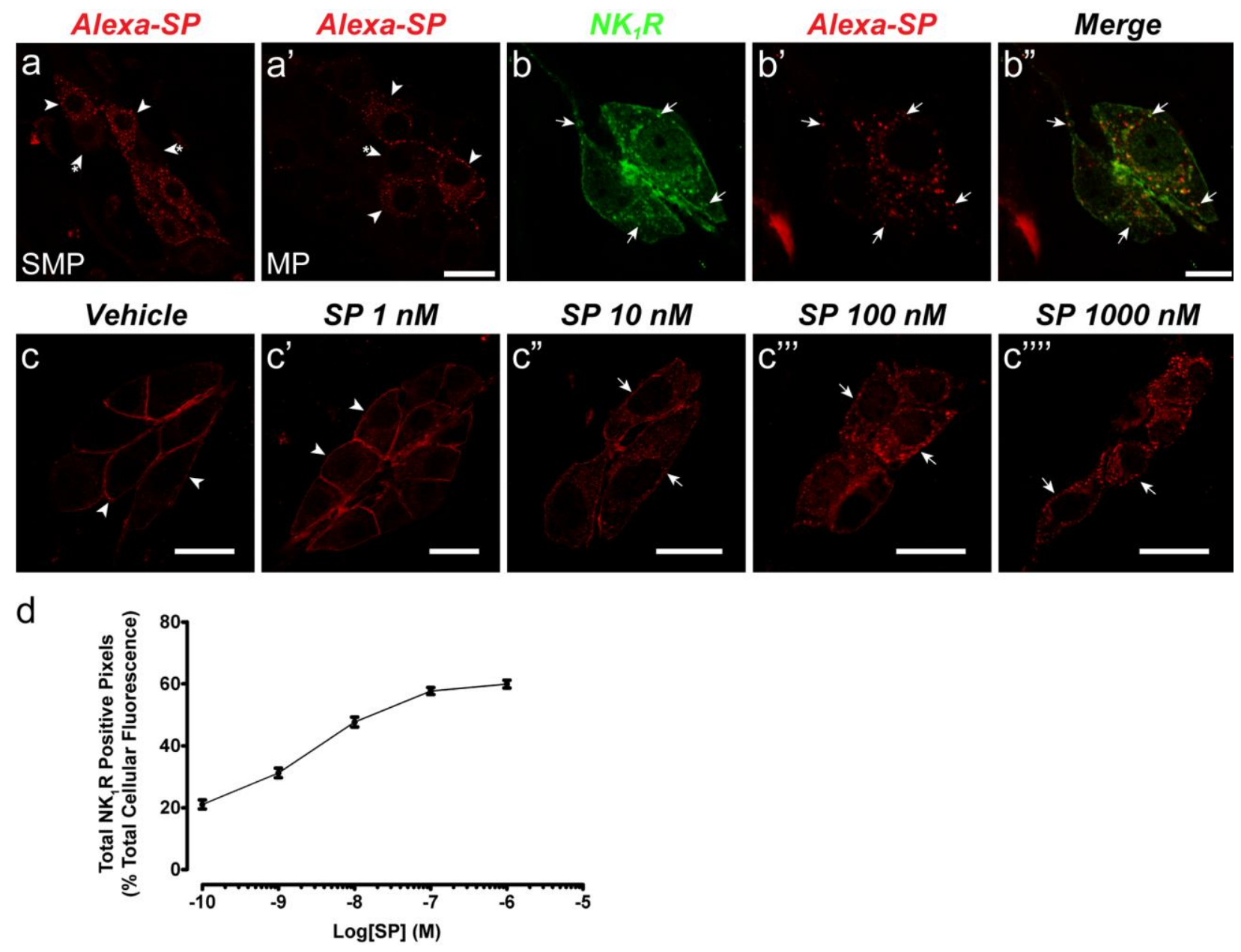

